\title{
IDENTIFICATION OF PROBLEMS AND SOLUTION OF THE MICRO SMALL MIDDLE ENTREPRISE WITH NVIVO-SOFTWARE
}

\author{
Siska Maya ${ }^{1)}$, Larisa Yohana ${ }^{2)}$ \\ ${ }^{1}$ Program Studi Pendidikan Ekonomi, FIPPS, Univ. Indraprasta PGRI \\ ${ }^{2}$ Program Studi Pendidikan Bahasa Inggris, FBS, Univ. Indraprasta PGRI \\ Email: may3110@yahoo.com; larisayohanna@gmail.com
}

Diterima: Juli 2018; Disetujui: Juli 2018; dipublikasikan: Agustus 2018

\begin{abstract}
ABSTRAK
Usaha Mikro Kecil Menengah (UMKM) adalah bahasan yang sangat menarik karena perkembangan UMKM sangat memberikan dampak yang baik terhadap perekonomian. Manfaat yang didapat oleh negara sangat banyak sekali dampaknya jika perkembangan UMKM semakin baik. Salah satunya adalah pengangguran akan semakin menurun karena dengan banyaknya UMKM bermunculan maka sangat berhubungan positif dengan kebutuhan tenaga kerja. Selain itu, dengan sedikitnya pengganguran tentunya akan meningkatkan kesejahteraan masyarakat. Rumusan masalah penelitian ini adalah apa saja yang menjadi hambatan Usaha Mikro Kecil Menengah selama ini dan bagaiman solusi jangka pendek yang dilakukan pemilik Usaha Mikro Kecil Menengah. Hambatan dan solusi yang diteliti adalah usaha mikro kecil menengah adalah 'shusimurah' yang sudah berjalan lebih dari 10 tahun.
\end{abstract}

Keyword : UMKM, Nvivo, Shusimurah

\begin{abstract}
Micro Small Medium Enterprises (MSME) is a very interesting discussion because of the development of SMEs are very good impact on the economy. The state gains some benefits and most impact if the development of MSME is better. One of them is unemployment will decrease because of with the number of UMKM emerging hence very positively related to labor requirement. Furthermore, decreasing unemployment will certainly improve the society's well being. The research aims at identifying what become obstacles of Micro Small Medium Enterprises so far and how short term solution done by the owner of Micro Small Medium Enterprises. Obstacles and solutions of small micro entreprise studied is 'shusimurah' that has been running for more than 10 years.
\end{abstract}

Keywords: UMKM, Nvivo, Shusimurah 


\section{PENDAHULUAN}

Usaha Mikro Kecil Menengah (UMKM) saat ini sudah bisa dikatakan menjadi tulang punggung bangsa indonesia. Dengan percepatan progres Usaha Mikro Kecil Menengah maka akan berdampak positif terhadap pertumbuhan ekonomi. Pertumbuhan ekonomi tinggi yang berkualitas tercipta jika rakyat kalangan paling bawah merasakan juga pertumbuhan ekonomi yang baik. Artinya kesenjangan ekonomi masyarakat antara lapisan semakin kecil. Salah satu dampaknya adalah memperkecil kecemburuan sosial.

Usaha Mikro Kecil Menengah (UMKM) adalah bahasan yang sangat menarik. Karena perkembangan UMKM sangat memberikan dampak yang baik terhadap perekonomian. UMKM memainkan peran peting dalam perekonomian regional. Kontribusi UMKM pada PDB dari $57,8 \%$ menjadi 60,34\% dalam lima tahun terakhir (2011-2016). Selain itu UMKM juga menyerap tenaga kerja dari $96,99 \%$ menjadi $97,22 \%$ pada periode yang sama. Peningkatan persentase ini memberikan dampak yang signifikan terhadap kesejahteraan masyarakat, khususnya masyarakat menengah.

Dukungan pemerintah juga banyak mengalami kemajuan yang cukup baik, terutama di sektor pembiayaan, pemerintah memudahkan UMKM dalam hal pembiayaan dan meringankan dalam masalah beban bunga. Perkembangan tahun 2016 bunga pinjaman untuk UMKM sebesar 9 persen dan pemerintah merencana penurunan bunga sebesar 1 persen di tahun berikutnya (http://ekonomi.kompas.com/read/2016/10/20/140829926/tahun.2017.suku.bunga.dana.bergulir. untuk.ukm.turun.di.bawah.7.persen). Dari laporan Bank Indonesia (2017) hingga juli 2017, pertumbuhan kredit UMKM mengalami perbaikan menjadi 8,31\% dari 7,41\% (yoy) pada bulan sebeumnya. Penyaluran KUR (Kredit Usaha Rakyat) sampai juli 2017 mencapai 47\% dari target (Rp 110T).

Berdasarkan Bank Indonesia (2017), UMKM memiliki kontribusi positif yaitu: 1). Tulang punggung perekonomian nasional karena populasi pelaku usaha dominan (99,9\%). 2). Menghasilkan PDB sebesar 59,08\% (Rp4.869,57 Triliun), dengan laju pertumbuhan sebesar $6,4 \%$ pertahun. Sektor ekonomi UMKM sebagi penyumbang PDB adalah Pertanian, peternakan, kehutanan dan perikanan (48,85\%); Perdagangan, Hotel dan Restoran (28,83\%); Pengangkutan dan Komunikasi (6,88\%); Industri Pengolahan (6,41\%); Jasa-jasa (4,52\%); Keuangan, Persewaan dan Jasa Perusahaan (2,37\%); Bangunan (1,57\%); Pertambangan dan Penggalian $(0,53 \%)$; Listrik, Gas dan Air Bersih (0,03\%). 3). Menyumbang volume ekspor mencapai 14,06\% (Rp166,63 triliun) dari total ekspor nasional. 4). Pembentukan Modal Tetap Bruto (PMTB) nasional sebesar 52,33\% (Rp830,9 triliun). 5). Secara geografis tersebar di seluruh tanah air, di semua area. Memberikan fasilitas pemenuhan keperluan pokok yang dibutuhkan masyarakat sehingga memiliki dampak multiplier yang tinggi. Hal tersebut merupakan instrumen pemerataan perolehan dan mengurangi ketakseimbangan kesejahteraan masyarakat. 6). Tempat untuk pembentukan wirausaha baru. 7). Ketergantungan pada faktor impor yang minimal dengan menggunakan bahan baku dan sumber daya lokal yang mudah ditemukan dan ada di sekitar sehingga menekan devisa.

Dari berbagai perizinan juga sangat dimudahkan dalam hal pemangkasan birokrasi. Di Istana Negara Presiden Joko Widodo menyatakan "deregulasi aturan menjadikan prosedur pendirian usaha UMKM kini semakin mudah, dengan total pemangkasan prosedur perizinan menjadi 49 tahap dari sebelumnya 94 tahap" (Bisnis.com April 2016). Selain itu, pusat layanan usaha terpadu (PLUT) Koperasi usaha mikro kecil menengah dibentuk oleh Kementrian Koperasi dan UKM. Layanan yang diberikan PLUT KUKM yaitu konsultasi bisnis, mentoring, dan lainnya yang berkaitan dengan perkembangan UMKM. (IFC, 2016).

Manfaat yang didapat oleh negara sangat banyak sekali dampaknya jika perkembangan UMKM semakin baik. Salah satunya adalah pengangguran akan semakin menurun karena dengan banyaknya UMKM bermunculan maka sangat berhubungan positif dengan kebutuhan tenaga kerja. Tentunya hal ini akan berdampak kepada meningkatnya kesejahteraan masyarakat 
akibat sedikitnya pengangguran. Jika dilihat dari sisi lainya UMKM juga sangat berpengaruh positif terhadap GDP suatu negara. Tambunan T (2008) mengatakan bahwa "...that both real gross domestic product per capita and goverment development expenditure (especially that used to finance SME development promotion programns) have positive impact on SME growth." Hal ini memberikan pandangan sejalan bahwa GDP berpengaruh positif terhadap perkembangan UMKM.

Pada saat ini perkembangan UMKM bisa dilihat sangat baik, terutama sektor makanan. Jika dibandingkan dengan unit usaha sektor lainya yang meningkat $0,98 \%$, laju pertumbuhan unit usaha kuliner lebih besar yaitu 1,48\%. Kontribusi sektor kuliner terhadap nilai tambah bruto dominan dibanding sektor lainnya sebesar $33 \%$.(Lazuardi M dan Triady,S. 2015)

Permasalahan dari sebuah umkm biasa adalah masalah permodalan, manajemen dan lainnya. Sepuluh permasalahan yang dihadapi oleh UKM yaitu hambatan persaingan, akses keuangan, harga modal, teknologi, tidak efisien biaya produksi, faktor-faktor ekonomi, manajemen, proses, keterbatasan dalam melakukan media penjualan, bahan baku. (Irjayanti, M dan Azis M A,2012).

Dukungan dari pemerintah terhadap usaha mikro kecil menengah merupakan suatu peluang yang harus di sambut dengan baik poleh para pengusaha. Oleh karena itu melalui penelitian yang berjudul "Identification of Problems and Strategies of the micro business with Nvivo" sangat perlu dilakukan agar mengetahui permasalahan sesungguhnya yang terjadi di masyarakat.

Dari pemaparan latar belakang masalah di atas, maka penulis merumuskan masalah sebagai berikut :Apa saja yang menjadi kendala Usaha Mikro Kecil Menengah selama ini dan bagaimana jalan keluar yang dapat dilakukan pemilik Usaha Mikro Kecil Menengah.

Berdasarkan uraian latar belakang diatas maka penelitian ini bertujuan : 1). Mengidentifikasi hambatan apa saja yang dialami oleh UMKM dilapangan? 2). Bagaimana solusi atas hambatanhambatan pengusaha UMKM dilapangan?

\section{Penelitian Usaha Mikro Kecil Menengah Terdahulu}

Dibawah ini adalah beberapa jurnal internasional yang dijadikan bahan referensi dalam penelitian ini :

Tabel 1. Mapping jurnal tentang usaha mikro kecil menengah

\begin{tabular}{|c|c|c|c|c|}
\hline No & Judul Penelitian & $\begin{array}{c}\text { Nama } \\
\text { Peneliti dan } \\
\text { Tahun }\end{array}$ & Metodologi & Hasil Penelitian \\
\hline 1. & $\begin{array}{l}\text { Microentreprise an } \\
\text { the Economic } \\
\text { Development } \\
\text { Toolkit: A Small Part } \\
\text { of the Big Picture }\end{array}$ & $\begin{array}{l}\text { Lisa J. Servon } \\
\text { dan Jeffrey P. } \\
\text { Doshna (2000) }\end{array}$ & kuantitatif & $\begin{array}{l}\text { Strategi yang dilakukan } \\
\text { terdiri dari } \\
\text { mengedukasikan } \\
\text { perencanaan } \\
\text { pengembangan ekonomi } \\
\text { dan pembuat kebijakan, } \\
\text { menintegrasikan } \\
\text { pengembangan usaha } \\
\text { mikro ke dalam rencana } \\
\text { pembangunan ekonomi } \\
\text { besar untuk daerah yang } \\
\text { tertinggal dan } \\
\text { mengevaluasi strategi } \\
\text { dengan menggunakan } \\
\text { tindakan yang tepat }\end{array}$ \\
\hline
\end{tabular}




\begin{tabular}{|c|c|c|c|c|}
\hline 2. & $\begin{array}{l}\text { Growth factors in } \\
\text { medium-sized } \\
\text { enterprise: the case of } \\
\text { an Italian region }\end{array}$ & $\begin{array}{l}\text { Lucio Cassia } \\
\text { dan } \\
\text { Alessandra } \\
\text { Colombelli } \\
(2010)\end{array}$ & kuantitatif & $\begin{array}{l}\text { Faktor yang signifikan } \\
\text { dalam menentukan } \\
\text { pertumbuhan usaha } \\
\text { menengah adalah } \\
\text { proaktif, sikap } \\
\text { mengambil risiko dan } \\
\text { investasi yang bertujuan } \\
\text { untuk pertumbuhan }\end{array}$ \\
\hline 3. & $\begin{array}{l}\text { Informattion systems } \\
\text { strategy development } \\
\text { and implementation } \\
\text { in SMEs }\end{array}$ & $\begin{array}{ll}\text { Martin Wynn } \\
(2009)\end{array}$ & kualitatif & $\begin{array}{l}\text { Delapan perusahaan } \\
\text { yang telah diteliti telah } \\
\text { berhasil dalam } \\
\text { menginvestasikan } \\
\text { informasi sistem dan } \\
\text { memberi manfaat }\end{array}$ \\
\hline 4. & $\begin{array}{l}\text { Small Medium } \\
\text { Entreprise's in India- } \\
\text { Issues and Prospects }\end{array}$ & $\begin{array}{l}\text { P. Suresh dan } \\
\text { Dr. M. Akbar } \\
\text { Mohideen } \\
\text { (2012) }\end{array}$ & $\begin{array}{l}\text { Kuantitatif } \\
\text { deskriptif }\end{array}$ & $\begin{array}{l}\text { Pengembangan usaha } \\
\text { kecil dan menengah di } \\
\text { India perlu peran } \\
\text { instansi pemerintah, } \\
\text { regulator dan lembaga } \\
\text { pembiayaan untuk } \\
\text { bersinergi }\end{array}$ \\
\hline 5. & $\begin{array}{l}\text { Co-opetition to } \\
\text { Promote Growth of } \\
\text { Batik Small and } \\
\text { Medium Enterprises }\end{array}$ & $\begin{array}{l}\text { Margani } \\
\text { Pinasti dan } \\
\text { Wiwiek } \\
\text { Rabiatul } \\
\text { Adawiyah } \\
\text { (2016) }\end{array}$ & kualitatif & $\begin{array}{l}\text { Persaingan antara } \\
\text { indutri kecil dan } \\
\text { menengah dalam } \\
\text { penelitian ini } \\
\text { menunjukan bahwa } \\
\text { pesaing melakukannya } \\
\text { tidak selalu membawa } \\
\text { dampak negatif. } \\
\text { Kolaborasi dengan } \\
\text { kompetitor bisa } \\
\text { menciptakan sinergi } \\
\text { yang mendorong } \\
\text { pertumbuhan industri } \\
\text { kecil dan menengah. }\end{array}$ \\
\hline 6. & $\begin{array}{ll}\text { An Assessment of } \\
\text { SME } \\
\text { Competitiveness in } \\
\text { Indonesia }\end{array}$ & $\begin{array}{l}\text { Setyawan } \text { Agus } \\
\text { Anton, Isa } \\
\text { Muzakan, } \\
\text { Wajdi Farid } \\
\text { Muhammad, } \\
\text { Syamsudin, } \\
\text { Nugroho } \\
\text { Permono Sidiq } \\
(2015)\end{array}$ & kuantitatif & $\begin{array}{l}\text { Penelitian ini } \\
\text { menjelaskan bahwa } \\
\text { persaingan usaha kecil } \\
\text { menengah pada tingkat } \\
\text { inovasi, } \\
\text { entreprenuership, } \\
\text { human capital, sumber } \\
\text { finansial, market yang } \\
\text { potensial dan strategi } \\
\text { bisnis. }\end{array}$ \\
\hline
\end{tabular}




\section{Usaha Mikro Kecil Menengah (UMKM)}

\section{Usaha Mikro}

Pengertian dari usaha mikro menurut undang-undang no 20 tahun 2008:83 pasal 1 adalah usaha produktif milik orang perorangan dan/atau badan usaha perorangan yang memenuhi kriteria Usaha Mikro. Berdasarkan Bab IV pasal 6 undang undang no 20 tahun 2008 kriteria usaha mikro adalah: 1. Memiliki kekayaan bersih paling banyak Rp. 50.000.000,00 (lima puluh juta rupiah) tidak termasuk tanah dan bangunan tempat usaha, 2. Memiliki hasil penjualan tahunan paling banyak Rp. 300.000.000,00 (tiga ratus juta rupiah).

Ciri-ciri usaha Mikro adalah: 1. Jenis barang/komoditi usahanya tidak selalu tetap, sewaktuwaktu dapat berganti. 2. Tempat usahanya tidak selalu menetap, sewaktu-waktu dapat berpindah tempat. 3.Belum melakukan administrasi keuangan yang sedarhana sekalipun, dan tidak memisahkan keuangan keluarga dengan keuangan usaha. 4. Tingkat pendidikan rata-rata rendah. 5. Umumnya tidak memiliki ijin usaha atau persyaratan legalitas lainnya, termasuk NPWP. 6. Umumnya belum akses kepada perbankan, tapi sebagian dari mereka sudah akses ke lembaga keuangan non Bank.

\section{Usaha Kecil}

Pengertian dari usaha kecil menurut undang-undang no 20 tahun 2008:83 pasal 1 adalah usaha ekonomi produktif yang berdiri sendiri, yang dilakukan oleh orang perorangan atau badan usaha yang bukan merupakan anak perusahaan atau bukan cabang perusahaan yang dimiliki, dikuasai, atau menjadi bagian baik langsung maupun tidak langsung dari Usaha Menengah atau Usaha Besar yang memenuhui kriteria Usaha Kecil.

Kriteria Usaha Kecil menurut undang-undang tahun 2008:87 pasal 6 adalah sebagai berikut: 1. Memiliki kekayaan bersih lebih dari Rp. 50.000 .000 (lima puluh juta rupiah) sampai dengan paling banyak Rp. 500.000.000,00 (lima ratus juta rupiah) tidak termasuk tanah dan bangunan tempat usaha: atau 2. Memiliki hasil penjualan tahunan lebih dari Rp. 300.000.000,00 (tiga ratus juta rupiah) sampai dengan paling banyak Rp. 2.500.000.000,00 (dua milyar lima ratus juta rupiah). Ciri-ciri Usaha kecil : 1. Jenis barang/komoditi yang diusahakan umumnya sudah tetap, tidak gampang berubah. 2. Lokasi/tempat usaha umumnya sudah menetap, tidak berpindah-pindah. 3. Pada umumnya sudah melakukan administrasi keuangan, walau masih sederhana, keuangan perusahaan sudah mulai dipisahkan dengan keuangan keluarga. 4. Sudah memiliki ijin usaha dan persyaratan legalitas lainnya, termasuk NPWP. 5. Pengusahanya sudah memiliki pengalaman dalam berwirausaha. 6.Sebagian sudah akses ke Bank dalam hal keperluan modal. 7. Sebagian besar belum dapat membuat menajemen usaha dengan baik.

\section{Usaha Menengah}

Pengertian dari usaha menengah menurut undang-undang no 20 tahun 2008; 83 pasal 1 adalah usaha ekonomi produktif yang berdiri sendiri, yang dilakukan oleh orang perorangan atau badan usaha yang bukan merupakan anak perusahaan atau cabang perusahaan yang dimiliki, dikuasai, atau menjadi bagian baik langsung maupun tidak langsung dengan Usaha Kecil atau Usaha Besar dengan jumlah kekayaan bersih atau hasil penjualan tahunan sebagaimana diatur dalam undang-undang.

Kriteria Usaha Menengah menurut undang-undang tahun 2008:87 pasal 6 adalah sebagai berikut: 1.Memiliki kekayaan bersih lebih dari Rp. 500.000.000,00 (lima ratus juta rupiah) sampai dengan paling banyak Rp. 10.000.000.000,00 (sepuluh milyar rupiah) tidak termasuk tanah dan banguan tempat usaha; atau 2. Memiliki hasil penjualan tahunan lebih dari Rp. 2.500.000.000,00 (dua milyar lima ratus juta rupiah) sampai dengan paling banyak Rp. 50.000.000.000,00 (lia puluh milyar rupiah).

Dalam perspektif usaha, UMKM diklasifikasikan kedalam empat kelompok, yaitu UMKM sektor informal, contohnya pedagang kaki lima ; UMKM Mikro adalah para UMK 
dengan kemampuan sifat pengrajin namun kurang memiliki jiwa kewirausahaaan untuk mengembangkan usahanya; Usaha Kecil Dinamis adalah kelompok UMKM yang mampu berwirausaha dengan menjalin kerjasama (menerima pekerja sub kontrak) dan ekspor; Fast Moving Entreprise adalah UMKM yang mempunyai kewirausahaan yang cakap dan telah siap bertransformasik menjadi usaha besar. (Bank Indonesia, 2015).

\section{Software Nvivo}

Nvivo adalah software yang membantu peneliti kualitatif dan mixed-methods pada saat menganalisa data dan juga sejak awal penelitian dilakukan. Nvivo adalah salah satu contoh QDAS (Qualitative Data Analysis Software). Pengembangan Nvivo terus dilakukan dengan umpan balik peneliti luas dengan keragaman metode mereka bekerja dengan data efisiensi yang diberikan oleh perangkat lunak melepaskan sebagian dari waktu yang digunakan untuk menata data dan memungkinkan peningkatan yang fokus pada cara-cara memeriksa makna dari apa yang tercatat. Fungsi dari komputer untuk pencatatan, pemilahan, pencocokan dan keterkaitan dapat dimanfaatkan oleh peneliti membantu menjawab pertanyaan peneliti, tanpa kehilangan akses ke sumber data atau konteks dari data.

Pat Bazeley \& Kristi Jackson (2013) mengatakan menggunakan Nvivo dalam melakukan analisi data kualitatif membantu dalam hal :

1. Mengatur data, Dalam mengatur dan mencatat banyak informasi yang masih berantakan yang masuk ke dalam sebuah data kualitatif. Hal ini bukan hanya file dari wawancara, kuisioner, observasi lapangan tetapi juga publikasi penelitian berupa jurnal, gambar, diagram, audio, video, halaman web, sumber dokumen lainnya, catatan, gagasan yang ditulis dalam memo, informasi tentang sumber data dan peta konsep dari apa yang ada didalam data.

2. Mengatur ide-ide, Dalam mengatur dan menyediakan akses yang lebih cepat ke konsep dan teori yang dihasilkan dalam proses penelitian, serta data yang mendukung, sementara pada saat yang sama mempertahankan akses ke konteks data tersebut berasal.

3. Data Query, Query data adalah berfungsi untuk mengaajukan pertanyaan sederhana atau kompleks terhadap data dan memiliki program mengambil dari database semua informasi yang relevan untuk menentukan jawaban dari pertanyaan mereka. Hasil query disimpan untuk memungkinkan pencarian atau interogasi lebih lanjut dan pencarian menjadi bagian dari proses penelitian yang sedang berlangsung.

4. Data visual, Data visual untuk menunjukan isi atau kasus, gagasan konsep, strategi sampling, waktu dan lain-lain. Hal ini dilakukan pada berbagai proses interpretasi secara visual mewakili hubungan antara variabel yang saling interaktif dalam tampilan.

5. Laporan dari data, Pada bagian ini menggunakan isi database kualitatif, termasuk informasi tentang sumber data asli, gagasan dan perkembangan pengetahuan peneliti dan proses dengan hasil yang tercapai.

\section{Kerangka Pemikiran}

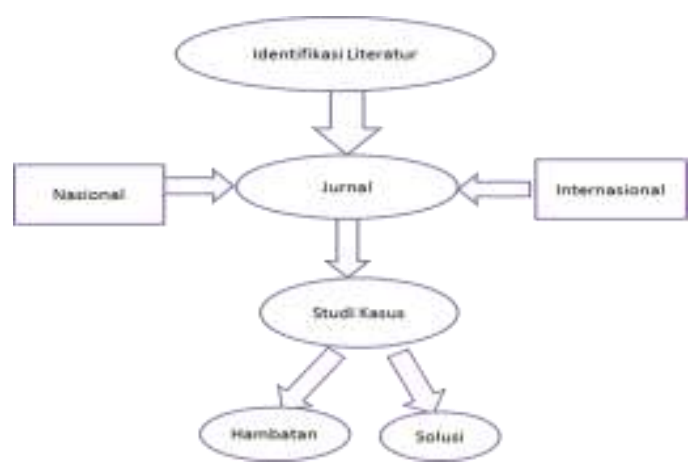

Sumber : Dikembangkan oleh Penulis, 2018 


\section{METODE}

Subyek penelitian ini adalah mengetahui hambatan dari usaha mikro kecil menengah dan memberikan solusi atas hambatan tersebut. Sedangkan obyek yang menjadi sasaran penelitian ini adalah usaha mikro kecil menengah yang bergerak di sektor kuliner. Lokasi penelitian berlangsung di Jakarta dengan melakukan observasi di wilayah yang ramai. Pemilihan sampel yang dilakukan yaitu pada Resto Sushimurah. Resto Sushimurah berlokasi di Jakarta Selatan.

Creswell,2005; Creswell\&Clark,2007 dalam Bandur 2016 menjelaskan rumusan tujuan dalam penelitian kualitatif mengidikasikan tujuan untuk mengekspolari, memahami dan menjelaskan gejala utama individu-individu yang hendak diteliti pada setting penelitian tertentu sekaligus untuk memecahkan masalah yang hendak diteliti. Creswell juga menjelaskan beberapa panduan dalam menyusun tujuan kualitatif yaitu: 1.Gunakan kata-kata kunci seperti mengeksporasi, menemukan, memahami, mendeskripsikan atau menjelaskan. 2. Menyatakan masalah utama yang hendak diteliti. 3. Sebutkan partisipan yang terlibat dalam penelitian

Marshall \& Rossman, 1999 dalam Bandur (2016) menyatakan bahwa tujuan penelitian kualitatif juga menjelaskan kepada pembaca tentang hasil-hasil penelitian yang akan dicapai peneliti. Mereka juga menjelaskan empat tujuan umum penelitian kualitatif yaitu: 1.Exploratory yaitu menginvestigasi fenomena penelitian yang belum dipahami secara utuh dan membangun hipotesis-hipotesis ubtuk tujuan penetian selanjutnya. 2.Explanatory yaitu menjelaskan polapola fenomena yang ada dalam data serta mengidentifikasi hubungan-hubungan yang terkait dengan fenomena utama. 3.Descriptive yaitu mendokumentasikan dan mendeskripsikan fenomena yang menarik perhatian peneliti. 4.Emancipatory yaitu menciptakan peluang dan hasrat untuk terciptanya tindakan akan perbaikan sosial

Rumusan masalah dalam penelitian kualitatif lebih terbuka dengan menggunakan pertanyaan-pertanyaan terbuka atau pertanyaan-pertanyaan yang lebih umum. Selain itu referensi lain yang digunakan melalui studi pustaka baik dari buku-buku ataupun jurnal nasional atau internesional terkait dengan penelitian.

Teknik pengumpulan data dengan pendekatan kualitatif yang diterapkan dalam penelitian ini adalah: 1. Studi literatur melalui buku, media cetak, maupun website, berupa data literatur, penelitian dan jurnal tentang usaha mikro kecil menengah dan juga usaha dibidang kuliner. 2. Observasi dilakukan terhadap usaha mikro kecil menengah (UMKM) di wilayah jakarta, 3. Wawancara atau interview dilakukan kepada pemilik resto Sushimurah. Pertanyaan-pertanyaan yang digunakan sifatnya pertanyaan terbuka. Interview mendalam juga dilakukan dalam penelitian ini.

\section{HASIL DAN PEMBAHASAN}

\section{Hasil}

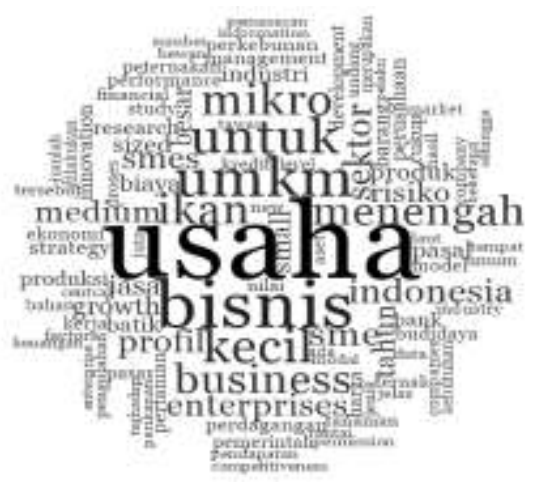

Gambar : Hasil Olahan Nvivo 
Jika dilihat dari gambar bahwa usaha didalam membuka bisnis sangat diperlukan. Hal ini bisa dilihat bahwa persentase usaha pada beberapa jurnal dan data lainnya menjadi dominan yaitu sebesar 1,74 persen. Hal ini menunjukan agar suatu bisnis bisa berjalan dengan baik, maka perlunya usaha. Usaha yang dilakukan bisa berupa inovasi-inovasi. Inovasi ini berkaitan dengan inovasi proses, inovasi produk dan ataupun inovasi kemasan. Hasil interview dari pemilik shushimurah juga kata usaha mendominasi 0,72 persen.

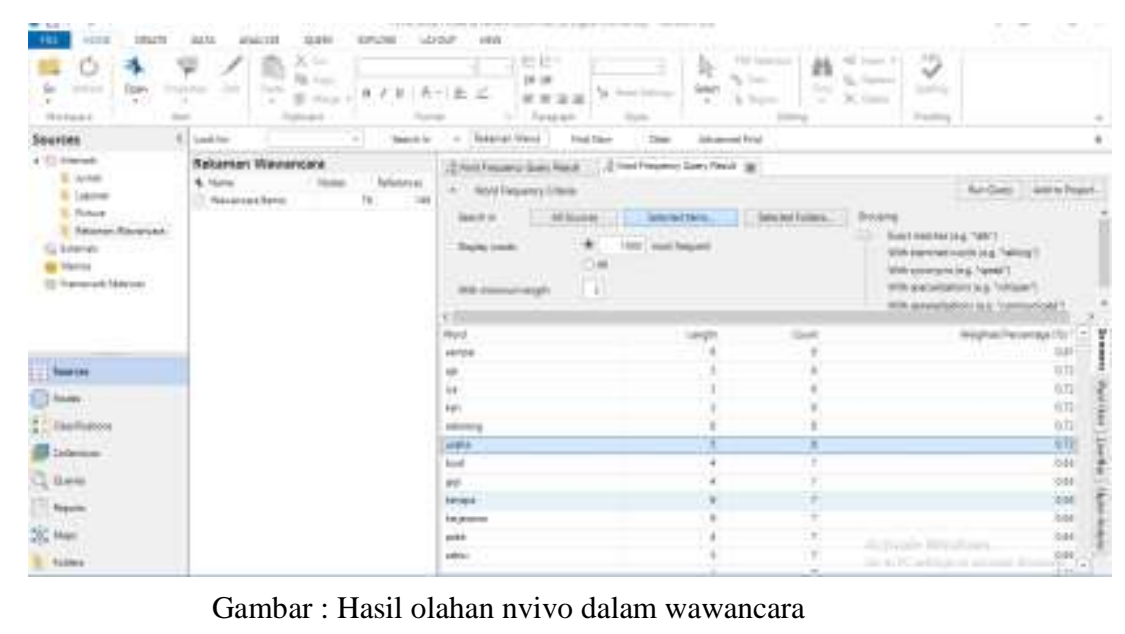

Peran pemerintah juga berperan penting. Hal ini tentunya akan mendorong pertumbuhan usaha mikro kecil menengah. Usaha mikro kecil menengah perlu mendapatkan perhatian karena tentunya telah memiliki kontribusi bagi pertumbuhan ekonomi Indonesia.

\section{Pembahasan}

Pertama kali dimulai usaha shusi (Resto Sushimura) ini adalah dari gerobak kaki lima selama tiga bulan. Setelah tiga bulan pemilik usaha ditawarkan kerjasama dengan kakaknya. Akhirnya kerjasama terjalin antara adik dan kakak. Awal kerjasama membuka shusi di kalibata city selama satu tahun. Kerjasama ini dengan ketentuan modal awal dari kakaknya dan skill atau keahlian dari pengusaha. Modal investasi yang ditanamkan di usaha ini sekitar 15.000.000. Motivasi ini juga dari istrinya karena sudah menjalankan usaha.

Pergantian tempat dilakukan dalam usaha ini adalah membuka usaha di Gedong Jakarta Selatan. Keinginannya untuk membuka usaha sendiri sangat besar menjadikan pengusaha ini meninggalkan kerja samanya dengan kakaknya. Keinginan membuka usaha sendiri termotivasi dari teman kerjanya. Sampai saat ini tetap berjalan dengan lancar walaupun banyak yang mengajak kerjasama. Pada awal buka di daerah gedong bulan november 2012 dengan sewa tempat seharga Rp. 3.750.000. Harga ini sudah termasuk fasilitas air, listrik, keamanan dan kebersihan.

Pengusaha ini sempat melakukan spekulasi karena makanan yang ditawarkan adalah makanan jepang. Pada saat awal usaha ini cukup diterima konsumen. Karena semakin lama semakin ramai. Usaha yang selalu berfluktuasi juga terjadi pada shusimurah. Usaha ini sempat tutup dan pindah ke daerah ambasador. Omset yang semakin menurun menjadikan usaha ini tutup di gedong. Karena ketidakmampuan untuk menutupi biaya operasional.

Namun ternyata sewa di ambasador lebih mahal Rp.6.000.000 dengan mempekerjakan karyawan dua orang. Pendapatan usaha ini lebih kecil operational cost sehingga usaha yang berlokasi diambasador terpaksa tutup. Pengusaha kembali lagi ke daerah Gedong, karena pengusaha mendapat harga khusus sewa dari pemilik tempat. Hal ini terjadi karena pengusaha menawarkan makanan yang penuh kreasi dan unik. 
Segmentasi pasar shusimurah ini adalah mahasiswa. Sehingga jam operasionalnya mengikuti perkuliahan. Operasional yang dilakukan senin sampai sabtu. Dengan jam operasional dari jam 10.00 sampai jam 21.00.

Dalam permodalan usaha, shusimurah tidak pernah menggunakan jasa bank. Hal ini dikarenakan banyaknya anggapan negatif tentang perbankan. Diantaranya adalah nasabah tidak bisa membayar dan disita barangnya. Hal ini yang membuatnya tidak meminjam di perbankan karena malu jika terjadi. Pengembangan usaha juga sempat dilakukan oleh pemilik shusimurah mulai dari rekrut karyawan. Namun menurut pemilik shusimurah adanya karyawan tidak memberikan dampak yang signifikan. Perbedaan proses makanan dari mulai pemesanan sampai ke konsumen hanya beda waktu yang tidak berbeda jauh dibandingkan dengan dikerjakan sendiri. Karyawan hanya membantu proses pengantaran dan cuci piring, sedangkan pembuatan shushimurah tetap dilakukan sendiri oleh pemilik shushimurah demi menjaga mutu dari makanan. Tempat yang kurang leluasa juga harus menjadi pertimbangan dalam menjalankan usaha.

Hambatan pengusaha shusimurah yaitu : 1. Peralatan shusimurah yang masih minim sehingga ketika pada saat waktu makan siang konsumen menunggu konsumen lain yang selesai makan, 2. Sulitnya mencari pegawai yang mau bekerja di tempat usaha shusimurah, 3.Tempat usaha dengan ruang terbatas menjadikan kendala atau pertimbangan dalam merekrut sumber daya manusia dan menambah usaha

Solusi pengusaha shusimurah yaitu: 1.Konsumen menunggu peralatan makan dari konsumen lain sampai selesai makan pada waktu siang. 2. Melakukan pekerjaan di tempat usaha hanya seorang diri. Mulai dari menerima pesanan, membuat pesanan konsumen, mengingat tempat duduk konsumen, mengantar makanan ke konsumen dan pembayaran konsumen. 3. Menyewa tempat usaha yang lebih luas agar dapat mengembangkan usahanya. Hal ini dilakukan sejalan dengan penambahan karyawan.

\section{SIMPULAN}

Permodalan bukan merupakan satu-satunya permasalahan yang paling besar dihadapi pengusaha UMKM. Permasalahan yang nyata dihadapi pengusaha adalah mental yaitu berani mengambil resiko, berkeinginan untuk lebih maju atau meninggalkan zona kenyamanan.

\section{SARAN}

Pengembangan usaha perlu di lakukan usaha Shushimurah, karena masih memiliki potensi pasar yang besar. Pengembangan dilakukan dengan membuka cabang baru. Investasi perlu ditingkatkan dalam hal peralatan makan dan perlengkapan makanaan. Pencatatan pembukuan laporan keuangan ataupun pemesanan dari konsumen perlu dilakukan. Hal ini bertujuan agar pengusaha dapat mengetahui dan memprediksi secara tercatat permintaan pasar yang terjadi setiap waktu. Selain itu dapat memperhitungkan dengan tepat laba yang diperoleh tiap bulan.

Dalam penelitian selanjutnya bisa melakukan observasi pada beberapa usaha mikro kecil menengah. Hal ini untuk membandingkan antara usaha mikro kecil menengah yang sejenis.

\section{DAFTAR RUJUKAN}

Bandur, A. (2016). Penelitian Kualitatif (Metodelogi, Desain, dan Teknik Analisis Data) dengan NVIVO 11. Edisi Pertama. Jakarta : Mitra Wacana Media.

Bazeley, P., \& Jackson, K. (2013). Qualitative Data Analysis with NVIVO. Singapura : SAGE Publications Asia-Pasific Pte Ltd 3 Church Street. 
Cassia, Lucio; Colombelli, Alessandra. (2009). Growth factors in medium-sized enterprises: the case of an Italian region. International Entreprenur Management Journal 6:437-458. Springer

Irjayanti,M dan Azis.M.A. (2012). Barrier Factors and Potential Solutions for Indonesian SMEs. Procedia Economics and Finance Elsevier

Lazuardi. M dan Triady S,M. 201). Ekonomi Kreatif: Rencana Pengembangan Kuliner Nasional 2015-2019. Jakarta : PT Republika Solusi

Paket Kebijakan XII: Perizinan UMKM Dipermudah http://finansial.bisnis.com/read/20160428/9/542829/paket-kebijakan-xii-perizina umkmdipermudah di unduh 17 Januari 2018 13:50

Perkembangan Terkini Asesmen Stabilitas Sistem Keuangan, September 2017. Departemen Kebijakan Makroprudensial. Bank Indonesia

Pinasti, Margani; Adawiyah,Rabiatul W. (2016). Co-opetition ti Promote Growth of Batik Small and Medium Enterprises. International Journal of Business and Society. Vol 17 No 3 pp. 401-412

Servon, Lisa J; Doshna, Jeffrey P. (2000). Microentreprise and the economic development toolkit: A small part of the big picture. Journal of Development Entrepreneurship Vol 5 No 3 p. $183-208$

Suresh,P; Mohideen, Akbar. (2012). Small Medium Enterprise's in India-Issues and Prospect. International Journal of Management Research and Review. Vol 2 Issue 2 No 4 pp 247255

Tahun 2017, Suku Bunga Dana Bergulir untuk UKM Turun di Bawah 7 Persen http://ekonomi.kompas.com/read/2016/10/20/140829926/tahun.2017.suku.bunga.dana. bergulir.untuk.ukm.turun.di.bawah.7.persen di unduh 17 Januari 2018 13:18

Tambunan, T. (2008). SME development, economic growth, adn goverment intervention in a developing country: The Indonesia story. Springer Science. Business Media

ton A Setyawan, dkk. (2015). An Assessment of SME Competitiveness in Indonesia. Journal of Competitiveness. Vol 7 Issue 2 pp. 60-74

UKM yang dimiliki Wanita di Indonesia : Kesempatan Emas untuk Institusi (Studi Penelitian Pasar). (2016). International Finance Corporation. World Bank Group dan USAID.Public Disclosure Authorized

Undang-undang Republik Indonesia Nomor 20 Tahun 2008 tentang Usaha Mikro, Kecil dan Menengah. Bandung : Citra Umbara Bandung. 2013. ISBN 978-602-9440-33-1

Wynn, Martin. (2009). Information system strategy development and implementation in SMEs. Emerald Group Publishing Limited Vol 32 No 1 pp. 78-90 